\title{
Aristoteles'in Adalet Anlayışı
}

\author{
Mehmet Çiçek ${ }^{\mathrm{a}}$
}

Özet

Aristoteles günümüz politika anlayışından oldukça farklı bir politika portresi çizmektedir. Ona göre politika insanın mutlu, erdemli, daha da önemlisi, insan olabilmesi için en önemli koşuldur. Bu perspektife bağlı olarak adalet öğretisi de biçimlenmektedir. Ona göre adalet, hak edene hak ettiği ölçüde hakkını vermektir. Hakkın ölçüsünün belirlenmesi, dağıtılan şeyin doğasına uygun yapılmalıdır. Başka bir ifadeyle dağıtılan şey, zenginlik, soyluluk gibi ölçütlere göre değil o şeyin doğasına uygun kimseye verilmelidir. Aristoteles adaleti yalnızca bir pay dağıtma olarak görmez, bunun yanında düzeltici ve değiş tokuş adaleti olarak iki farklı adalet türünden de söz etmektedir. Bu çalışma, Aristoteles'in politika, erdem ve adalet ilişkisini inceleyerek, günümüz politik problemlerinin çözümlerine katkı sunmayı amaçlamaktadır.
Anahtar Kelimeler

\begin{tabular}{r} 
Adalet \\
Politika \\
Etik \\
Erdem \\
Makale Hakkında \\
\hline Geliş Tarihi: 25.11.2019 \\
Kabul Tarihi: 25.12 .2020
\end{tabular}

Doi: $10.18026 /$ cbayarsos.650770

\section{Aristotle's Understanding of Justice}

\begin{abstract}
Aristotle paints a very different policy portrait from today's policy understanding. According to him, politics is the most important condition for the human being to be happy, virtuous, and more importantly, human. Depending on this perspective, the doctrine of justice is also shaped. According to him, justice, to the extent that it deserves the right to give. The determination of the right should be done according to the nature of what is distributed. In other words, what is distributed should be given to someone who is in accordance with the nature of that thing, not according to criteria such as wealth and nobility. Aristotle not only sees justice as distributing a share but also speaks of two different types of justice, corrective and exchange justice. This study aims to contribute to the solution of today's political problems by examining Aristotle's relationship between politics, virtue and justice.
\end{abstract}

Keywords

Justice

Policy

Ethics

Virtüe

\section{About Article}

Received: 25.11.2019

Accepted: 25.12.2020

Doi: 10.18026/cbayarsos.650770

\footnotetext{
a Bursa Uludağ Üniversitesi, Felsefe Bölümü, Doktora Öğrencisi, mehmetcicek3521@gmail.com, ORCID: 0000-0003-0250-5005
} 


\section{Giriş}

İnsan yaşamının temelinde yer alan, bireysel ilişkilerden devletin yönetimine kadar nerdeyse her alanda etkisini gösteren ve oldukça önem atfedilen bir kavram olan adalet hem taşıdığ anlam hem de toplumsal düzen içinde tesis edilme kaygısıyla aslında insanlık tarihi kadar eski bir arzu, özlem ve aynı zamanda problem anlamına gelmektedir. Toplumsal, politik ilişkilerin değişkenliği ve iktidarların güçleri ölçüsünde anlamını belirleme meşrutiyetini kendilerinde görmeleriyle birlikte pratik yansıması çağlar boyu değişen adalet kavramı, bir problem olarak yakınımızda, hayatın içinde olmuştur. Aynı zamanda adalet, tarih boyunca sürekli özlem duyulan bir arzu nesnesi olarak her zaman uzaklarda, aşkın bir yerlerde konumlanmıştır. İnsanın olduğu bir yerde adil bir düzenin tesis edilmesinin imkan(sılığ)1, en az adaletin ne olduğu kadar önemli bir problemdir. Tüm bu sorunların çözümleri belirsiz olsa da kesin olan, Antik dönemde yaşamış olan Yunanlıların, adaletin hüküm sürdüğü bir toplumun inşa edilmesinin mümkün olduğuna dair katışıksız bir inanca sahip olmalarıdır.

Yunanlılar için insan, tek başına yaşayan bir varlık değil o, toplumla var olan, toplumla anlam ve değer kazanan bir varlıktır. Bir Yunanlının edimlerinin, kahramanlıklarının ve herhangi bir alanda başarı isteğinin temelinde genel anlamda toplumda onur, saygınlık ve şan elde etmek vardır. Dolayısıyla Antik dönem Yunan uygarlığında toplum, insan yaşamının devamı için adeta bir vazgeçilmez bir koşuldur. Bu düşünce şekli, yansımasını en çarpıcı biçimde Aristoteles'in insan politik bir canlıdır ifadesinde bulmaktadır. Aristoteles için poliste yaşamayan biri ya insandan üstündür ve polise ihtiyaç duymadığı için Tanrıdır ya da insandan aşağı bir canlıdır. Yunan toplumu günümüz kentlerine nazaran oldukça küçük sayılabilecek polis adıv verilen, politik bir düzenin, meclisin ve bürokrasinin olduğu şehir devletlerinde yaşarlardı. Ancak günümüzde "devlet" denildiğinde akla gelen şey ile bir Yunanlının o dönemde polisten anladığı şey arasında oldukça fark vardır. Polis, yurttaşlar için bürokrasi ya da devleti oluşturan kurumlardan çok, yurttaşların birbirleriyle veya devletle olan ilişkilerini belirleyen ve kapsayan bir şeydir. Nitekim Themistokles Pers savaşlarından önce polisi taşıma fikrini meclise önerdiğinde kastettiği şey kurumlar veya kenti oluşturan yapılar değil, Atina toplumunu oluşturan insanların yer değiştirmesiydi. Dolasıyla polis bir Yunanlı için, daha önce denildiği gibi, yaşamın kendisiydi.

Arkaik çağdan itibaren polislerin sayılarının yükselmesi ve klasik formuna erişmesiyle birlikte, adalet kavramı, basit insani ilişkilerle biçimlendirilen anlamlarının yanında, politik bir anlam da kazanmaya başlamıştır. O dönemlerde yaşanan rejim değişiklikleri, hukuki dönüşümler, savaşlar gibi birçok yıkıcı veya devrimsel olay, adaletin, Yunanlılar için değeri giderek artan, edebi-sanatsal eserlerin ve felsefenin ana meselelerinden biri haline gelmesine sebep olmuştur. Ancak felsefe söz konusu olduğunda gözden kaçmaması gereken nokta şudur: O dönemdeki teorik tartışmalarda bile adalet, pratik bağıntılarından koparılmış soyut bir kavram olarak ele alınmamıştır. Bu konuya, Platon'un felsefe anlayışı örnek olarak gösterilebilir. Buna bağlamda, Platon için (aynı zamanda onun dönemi için de) salt teorik bir tartışmadan ya da pratik karşılığı olmayan diyalektik bir akıl yürütmekten bahsetmek çoğu zaman güçtür. Başka bir ifade ile Platon, ne zaman cömertlik, erdem, iyilik, adalet vb. ahlaki kavramları tartışırsa tartışsın, aklında her zaman polıteiā(devlet, rejim, yönetim şekli) vardır. Platon'un felsefesinin merkezinde, ömrünün son dönemlerine kadar, politikaya yani polise dair problemler bulunmaktadır. Nitekim son eseri olan Yasalar politikaya dairdir. Bunun nedeni, daha önce değinildiği üzere, diğer tüm Yunanlılar için olduğu gibi Platon için de, 
insanın polis içerisinde bir "anlam" ifade ettiği ve yine ancak orada mutlu olabilme imkânına sahip olduğudur.

Adalet kavramına felsefi bir anlam/işlev kazandıran ilk filozof Anaksimandros'tur. Evrende bulunan şeylerin kendisinden geldikleri şeye zorunlu olarak geri döneceklerini ifade eden Anaksimandros, bunun sebebini yapmış oldukları adaletsizliklerin cezasını çekmeleri ve birbirlerine kefaretlerini ödemelerine bağlar. (Jaeger, 2012, s.52) Anaksimandros'un fragmanını yorumlarken, bunu "ilk felsefi teodise" olarak nitelendiren Jaeger'e göre "söz konusu dönem, adalet fikrinin, devlet ve toplumun üzerine inşa edilmesi gereken bir çağdı; dolayısıyla adalete sadece bir uzlaşma olarak değil bizzat gerçekliğin içinde her yerde hazır, nâzır bulunan etkin bir norm olarak bakılıyordu."(Jaeger, 2012, s.53) Başka bir ifadeyle, adalet fikrinden genel anlamda eşitliği anlayan ilk dönem filozofları için adalet, toplumsal düzenin temelini oluşturan bir normdur. Bu anlamda adaletsiz olarak nitelendirilen herhangi bir davranışın karşılığını bulması kaçınılmazdır.

Herakleitos söz konusu olduğunda ise Platon ve Aristoteles' in iddia edeceğinden farklı olarak adaletin bilinirliğini karşıtının varlığına bağlamaktadır. Platon ve Aristoteles için kötü, çirkin şeylerin herhangi bir ontolojik gerçekliği yoktur; bunlar, iyi, güzel olarak nitelendirilebilecek karşıtıyla bilinir: Örneğin onlara göre hastalığı sağlıktan ötürü biliriz. Bu konuda Herakleitos şunu dile getirir: "Adaletin adı bilinmezdi, bu şeyler [adaletsizlikler] olmasaydı." (Herakleitos, 2019, s.75) Dolayısıyla Herakleitos' ta adalet söz konusu olunca 'negatif' anlamda bir bilme karşımıza çıkar. Başka bir ifadeyle, adalet, Herakleitos felsefesine uygun olarak, karşıtıyla bilinir. Bu zıtlıkların çatışması sonucunda adalet yani düzen açığa çıkar. Bununla birlikte Herakleitos' un öğretilerinde adalet kavramının kozmolojik bir işlevi de vardır. Adalet, Herakleitos için zıtlıklar arasındaki dengeyi sağlayan, evrenin düzenleyici bir unsurudur. Benzer bir tanımlama Parmenides'in düşüncelerinde de görülmektedir. Nitekim ona göre, adalet Tanrıçası Dike, hem sanılar dünyasının hem de hakikatler dünyasının düzenleyicisi, bir arada tutan unsurudur.

Pers savaşlarından sonra (M.Ö. 5. yy.) Atina, sosyo-kültürel anlamda birçok farklı kültür ve toplumla karşılaştı. Farklılıkları gören Yunanlılar, nomosun, dinin veya diğer felsefi argümanların değişmez oldukları yönündeki yaygın inanca şüpheyle yaklaşmaya başladılar. Bu anlamda "artık öz-bilinç gelişiyordu" (Copleston, 2009, s.76) demek yanlış olmayacaktır. Bunun yanı sıra, gelişen ve güçlenen politika alanı her gencin ilgi odağı haline gelmeye başlamıştı ve bu alanda kendini göstermek, yeni yöntemler ve eğitimlerle daha hızlı bir şekilde olanaklı hale geliyordu. Zira retorik artık politik hırsların, aldatmacaların ve kariyer elde etmenin en önemli aracı haline gelmişti. Tüm bu koşul ve gereksinimler Sofistlerin ortaya çıkmasına zemin hazırlamıştır. Öte yandan Sofistlerin ortaya çıkmasında yalnızca politik nedenler değil aynı zamanda felsefi nedenler de etkin rol oynadı. Doğa filozoflarının karşıt ve aynı derecede doğru savları, Parmenides, Zenon ve Herakleitos ile zirveye çıan duyusal dünyanın değiştiği ve ona dair her bilginin sanıdan öteye geçmediği, dolayısıyla duyu organlarımızın bizi yanılttığı öğretileri bu felsefi nedenler arasında sayılabilir. Böylece dikkat sofistler döneminde özneye dönmeye başlar, ancak "kuşkucu bir perspektifle." (Copleston, 2009, s.75) Sofistler öznel duruşlarından adalet kavramının tanımı konusunda da geri durmamışlardır. Onlara göre değişmez tek bir adalet yoktur aksine koşullara, topluma ve zamana göre değişen adaletten söz etmek mümkündür. Ancak politik düzen ve yönetim söz 
konusu olduğunda Sofistler "nesnel" sayılabilecek bir tutum takınırlar. Bu nesnel ölçüt, birbirlerinden farklı tanımlanabilecek doğrular, iyilikler ve adil olanlar noktasında uzlaşım sağlanması anlamına gelmektedir. Bu anlamda her sitenin, bir başka siteden daha doğru olmaksızın, kendi doğrusunu, kendi iyisini ve adil olanı belirledikten sonra ona bağlı olarak bir yasal düzen kurması gerekmektedir. (Copleston, 2009, s.82)

Sofistlerin felsefi rölatif tutumu Platon'un sofist düşmanlığını anlaşılmasına yardımcı olur; nitekim ona göre artık gerçeği arama ruhu kaybolmuştur. Çünkü hakikat, sofistler için koşul, yer, zaman ve insan ile hayati bir bağ içerisindedir. Bunun yanı sıra, Platon'a göre, Sofistler, toplumdan topluma, kişiden kişiye değişen bilgiyi ve değer yargılarını öğretmekteydiler. Dolayısıyla onun için bu türden bir etik ve politik anlayış, yozlaşmışlığın ve karışıklığın hâkim olduğu bir toplum yaratmaktadır. Sofistlerin aksine Platon için hakikat, yere ve zamana göre değişmeyen, toplumu mutluluğa ve düzene ulaştıran türden bir şeydir. Bu yüzden her topluma ve kişiye göre değişen bir adalet fikri, adil bir toplum yaratamaz. Sofistler'e yapılan bu eleştirilerde Platon bir bakıma haklı görünse de Sofistler'in toplum düzeni için asgari düzeyde bir uzlaşma yolunu benimsediklerinin göz ardı edildiğini belirtmekte fayda vardır. Başka bir ifadeyle, Sofistler'e göre değişken değer yargıları söz konusu olsa bile, adil bir toplum yaratmak için insanların sağduyularına uygun ve uzlaşabilecekleri yasalar bulunabilir.

Değişmez, evrensel bir adalet tanımı olduğunu düşünen Platon, her şeyden önce, adaleti erdem ideasının, diğer üç parçası ile birlikte (bilgelik, yiğitlik, ölçülülük), bir parçası olarak tanımlar. Bir diğer ifadeyle, bu dört erdem duyusal dünyada sahip olunabilecek niteliklerdir; tek bir erdem ideasına bağlıdırlar ve ondan pay almaktadırlar. (Arslan, 2006, s.98) Erdemli bir insan olmak için gerekli olan bu parçalar arasında adalet, ona göre daha kapsayıcı ve temel olandır. Çünkü adaletten yoksun yiğitlik, bilgelik ve ölçülülük erdemleri bir anlam ifade etmeyecektir. Bu bağlamda Platon'un diyaloglarında doğruluk ve adalet kavramlarını birbirlerinin yerine kullandığını belirtmekte fayda vardır. Zira ona göre doğru bir edim aynı zamanda adil bir davranış anlamına gelir. Dolayısıyla bilgece, ölçülü ya da yiğitçe olarak nitelendirilen her davranış son kertede doğru/adil olanın altına yerleştirilebilir. Bunun yanında, Platon adaletin anlamını eşiklikte de bulmaktadır. Ancak eşitliği iki farklı anlamda kullanır. Oy kullanma, yasaların düzeninde söz sahibi olabilme gibi niceliksel bir eşitliğin yanı sıra, onun nazarında eşitlik, herkese aynı payı vermek değil, büyük olana büyük, küçük olana küçük payı vermek demektir. (Platon, 2012, s.221-222) Adaletin hak edene hak ettiğini verme biçimindeki tanımı, Aristoteles'in felsefesine de etkide bulunmuştur ancak Aristoteles özellikle adalet konusunu daha ayrıntılı ele almaktadır.

Değinildiği üzere, Aristoteles'te Platon'dan çok farklı bir adalet erdemi yoktur. Ancak Platon adaleti ideal bir devlet tasarımı üzerinde temellendirirken, Aristoteles var olan devlet düzeni ve toplumdan hareketle temellendirir. Gerektiği zaman gerektiği şekilde davranmak Aristoteles'in etik anlayışının vazgeçilmez ilkesidir. Bu anlayış, onun adalete bakışının da anlaşılmasını sağlamaktadır. Dolayısıyla Aristoteles için adaletin temel bir tanımı olsa bile duruma göre değişen pratik uygulamaları da mümkündür. Yasaya uyan, eşitliği gözeten kişilerin adil olduğunu ve buna uygun yasaların da adil yasalar olduğunu ifade eden Aristoteles, eşitliğin niteliksel yanı kadar niceliksel yanlarını da inceler. Adaleti dağıtıcı adalet, düzeltici adale ve değiş tokuş adaleti olarak ele alır. Ancak o da Platon gibi niteliksel anlamda 
bir eşitlik/adalet fikrine sahiptir. Ona göre hak ederek bölüşülen paylar, herkese aynı payın verilmesinden daha adildir. Aristoteles için "adalet, en toplumsal, en politik erdemdir. $\mathrm{O}$ sitenin uyumlu ve istikrarlı bir şekilde tesis edilmesini ve devamını mümkün kılar; politik iyinin kişisel veya bireysel iyiyle ilişkisi neyse, en yüksek politik erdem olan adaletin diğer erdemlerle ilişkisi odur. Politikanın ahlâkla ilişkisi neyse, adaletin diğer erdemlerle ilişkisi odur." (Arslan, 2009, s.264) Bu anlamda Aristoteles, adaletin de diğer erdemler gibi bir tür orta olduğunu, haksızlık etmekle haksızlığa uğramanın ortasında olduğunu belirtir.

Son olarak, Aristoteles, Sokrates'in (Platon'un) erdem bilgidir anlayışının doğru, ancak eksik olduğunu dile getirmektedir. Ona göre adil biri olmak için adaleti bilmek yetmez onu huy veya alışkanlık haline getirene kadar eylemimizi tekrarlamamız gerekmektedir:

Sokrates, amaç erdemi bilmektir diye düşünüyordu ve adaletin ne olduğunu, yiğitliğin ne olduğunu, yani her erdem parçasını soruşturuyordu. Böyle yapması yerindeydi, çünkü o erdemlerin bilgi olduğunu, dolayısıyla adaleti bilince aynı anda adil olunacağını düşünüyordu. ... erdemle ilgili olarak, onun ne olduğunu bilmek değil, erdemin nelere bağlı olarak oluştuğunu bilmek en önemli şey. Çünkü bizim istediğimiz erdemin ne olduğunu bilmek değil, erdemli olmak; adaletin ne olduğunu bilmek değil, adil olmak. (Aristoteles, 2015a, s.15)

Dolayısıyla Aristoteles'e göre etik söz konusu olduğunda teorik bilginin yanında pratik alan da oldukça önemlidir.

\section{Aristoteles Felsefesinde Mutluluk ve Erdemlerin Varoluş Koşulu Olarak Politika ve Toplum}

Aristoteles Platon gibi adalet ve hak arasında bir ilişki olduğunu düşündügüne yukarıda değinilmişti. Ancak buradaki sorun, kimin neyi hak ettiğini belirleyen ölçütlerin neler olduğu problemidir. Aristoteles için bu ölçüt her şeyden önce dağıtılan şeyle ilgilidir. Bir diğer ifadeyle, bir şeyin adil dağıtılması için dağıtılacak şeyin telosunun belirlenmesi gerekmektedir ve böylece dağıtılacak şey onun telosuna en uygun kişiye verilmelidir. Örneğin bir flütün dağıtılması söz konusu ise, bu flüt zengin, doğuştan soylu olan ya da diğer üstünlüklere sahip kişiye değil flütü en iyi kullanabilen kişiye verilmelidir. (Sandel, 2017, s.248-251)

Adalet denilince günümüzde genelde refah ve fırsatların dağıtımı ile ilgili konular akla gelirken Aristoteles ise adaletin maddi kaynakların yanında politik görevler ve onur gibi durumlarla da ilgili olduğunu düşünmektedir. Dolayısıyla yönetme işini kime verilmesi gerektiği konusu da toplumsal adalet için önemli bir sorundur. Aristoteles söz konusu olunca bunun için öncelikle politik birliğin veya politikanın amacının belirlenmesi gerekmektedir. Modern toplumlarda bireysel özgürlük isteği ve kaygısıyla politikanın varlık sebebi, en temel anlamda, insanların amaçlarını seçmelerine ve gerçekleştirmelerine olanak sağlayan "prosedür" olarak belirlenir. Ancak Aristoteles için politikanın amacı "amaçlar arasında nötr olacak bir haklar çerçevesi düzenlemek" değildir. Ona göre politikanın amacı toplumun mutluluğu ve bunun için de iyi karakterli yurttaşların yetişmesi için uygun yasalar belirlemektir. (Sandel, 2017, s.255) 
Aristoteles oldukça çarpıcı bir kent (siyasal birlik, toplum) tarifi yapmaktadır. Ona göre bazılarının iddia ettiği gibi kent iyi yaşam için değil de yalnızca yaşamak için var olsaydı, kölelerden veya hayvanlardan oluşan bir kent mümkün olabilirdi. Ya da kent, bir savunma veya ticari ittifak gereği kurulan bir şey olsaydı, antlaşmalarla birbirine bağlanan kentler tek bir kent olurlardı. Oysa bu türden ittifaklar hem ortak makamlara sahip olmamaları hem de erdeme dair ortak bir kaygı taşımamaları nedeniyle bir kent değillerdir. Aksi durumda kent ittifakın başka bir ifadesi olur ve siyasal birlik ittifaka tabi olurdu. Halbuki Aristoteles için bir kentin karakteristik niteliği salt yaşamı değil, iyi ve güzel bir yaşamı olanaklı hale getirmesidir. Dolayısıyla, özgür, soylu ya da zenginlik yurttaşın daha fazla pay alması gerektiğini göstermez; bunu yalnızca güzel işlere katkıda bulunanlar yani erdem konusunda üstün olanlar hak eder. (Aristoteles, 2018, s.278-279)

Aristoteles, bir kenti yönetmeye genelde talip olan ve bu hak iddia eden iki kesimden söz etmektedir: Bunlar oligarşi ve demokrasi yanlılarıdır. Oligarklar zenginlerin iktidarını meşru görürken demokratlar ise özgür doğmanın, yurttaşlık ve politik yönetim için yegâne kriter olduğunu savunmaktadırlar. Aristoteles, söz konusu iki grubun otorite taleplerinin altında, politik birliğin amacının yanlış yorumlanması yattığını düşünmektedir. Politik birliğin amacı ne mülkiyeti korumak ya da ekonomik refahı geliştirmek ne de çoğunluğun tercihlerini veya isteklerini karşılamak değildir. Başka bir ifadeyle devlet "karşılıklı korunma için bir ittifak, ekonomik mübadeleleri kolaylaştırmak ya da ekonomik ilişkileri geliştirmek" için var olmamıştır. Politikanın amacl, "insanların farklı insan kapasitelerini ve değerlerini geliştirmelerine imkân vermekten, ortak iyi hakkında düşünmekten, pratik muhakeme yeteneği elde etmekten, kendi kendini yönetmeyi paylaşmaktan, bütün olarak toplumun geleceğini önemsemekten daha az bir şey değildir." (Sandel, 2017, s.256-257) Aristoteles, politikanın amacını sözü edilen biçimde tanımlamasından sonra ortaya çıkan şu soruların cevapları belirmeye başlamaktadır: Aristoteles neden politikayı insan hayatının ve mutluluğunun temeline yerleştirmektedir? Politika veya toplum olmadan neden insan erdemli, iyi bir yaşam süremez? Aristoteles'in perspektifinde bu soruların yanıtları insan doğası ile ilişkilidir. Çünkü sadece bir politik birlik içinde ve politikaya katılarak insani doğamızı gerçekleştirebiliriz. Aristoteles bu düşüncesini, sadece insanın dil kullanabilen canlı olmasıyla temellendirmektedir. Ona göre insan, yalnızca politik bir birlik içinde dil yeteneğini kullanabilir ve diğer insanlarla adalet, adaletsizlik veya iyi bir hayatın doğası gibi konular hakkında tartışabilir. (Sandel, 2017, s.260) İnsan yalnızca diğer insanlarla birlikte yaşayarak bu türden 'entelektüel' yetkinliklerini geliştirebilir.

Politik bir birlik içinde yaşamanın bir diğer zorunluluğu (doğal zorunluluk) ise erdemli bir hayatın koşulu olmasıdır. Aristoteles için bir kişinin erdemli olarak nitelendirilebilmesi için bu konuda üstün bir teorik bilgiye sahip olması yetmemektedir; o, defalarca tekrarlanıp alışkanlık ya da huy haline getirildiği taktirde erdem haline gelir. Dolasıyla bunun için hali hazırda politik bir birlik içinde yaşamak gerekmektedir. Bu noktada Aristoteles' in adaleti de içine alan erdem anlayışından genel anlamda bahsetmek yerinde olacaktır. Buna göre erdemli bir davranış her şeyden önce orta olmayı gerektirmektedir. Örneğin, çok para harcamak müsriflik, az para harcamak cimriliktir; cömertlik ise bunların ortasıdır. Ancak Aristoteles de bu genel yargının her durumda geçerli olmadığının farkındadır. Dolayısıyla o, doğru davranışın, doğru zamanda ve doğru yerde yapıldığı takdirde ortaya çıkacağını söyler. Bu 
noktada doğru zaman ve koşulun nasıl belirleneceği problemi ortaya çıkmaktadır. Aristoteles için kişi pratik akıl dediği akıl türüne sahip olduğu ölçüde bunu belirleyebilmektedir. Ancak Aristoteles için bu türden bir düşünme "filozofça" düşünme değildir. Çünkü bu konu evrensel, mutlak olanla değil değişebilir, tikel olanlarla ilgilidir. Tüm bu söylenenlerin neticesinde Aristoteles için politikanın hayati önemi netleşmiş olmaktadır: Buna göre "ilk olarak şehir devletinin kanunları iyi eylemleri aşılar, iyi karakter oluşturur, yurttaşlık erdemine yönlendirir. İkinci olarak vatandaşın hayatı, müzakereyi ve aksi takdirde aktif olmayacak pratik akıl kapasitesini gerçekleştirmemize imkân sağlar" (Sandel, 2017, s.263-264) ve bunlar da toplumdan bağımsız yapılacak şeyler değildir.

\section{Aristoteles Felsefesinde Adalet Kavramı}

Aristoteles adalet konusunu ele alırken biçimsel olarak onayladığı, şu tanımları verir: Adalet, insanların adil olanı yapmalarını ve haklı şeyler istemelerini sağlayan huydur. Adaletsizlik ise insanları haksızlık yapmaya ve haksız şeyler istemeye götüren huydur. Akabinde Aristoteles, bir huyun karşıtından yola çıkılarak bilinebileceğini söyler. Karşıtların arasındaki bu bağa dikkat çeken Aristoteles, bu anlamda adil olanın birkaç anlamı varsa adaletsizliğin de birkaç anlamı olacağını söyler. Sonrasında, adaletsizlikten hem yasaya uymayan insanın hem çıkarcı insanın hem de eşitliği gözetmeyen insanın huyu olarak söz edildiğinden bahseder. Dolayısıyla adil olan da yasaya uyan, eşitliği gözeten ve çıkarcı olmayan insan olacaktır. Aristoteles'e göre yasalar bakımından uygun olan şeyler adil olarak adlandırılıyorsa, yasal olan şeyler bir bakıma adil şeylerdir. Ancak Aristoteles'in bu noktada iyi yasalar ön kabulüyle konuştuğunu gözden kaçırmamak gerekmektedir. Aristoteles iyi yasalardan politik toplumun mutluluğunu, onun öğelerini hedefleyen şeyi anlar. (Sandel, 2017, s.90-92) Bu anlamda, politik toplumun yaratılması ve devam ettirilmesi için doğru kurallar olmaları bakımından yasaların adil olduğu veya adaletin uyma, birinci ve genel anlamının yasalara uygun olma, ona itaat etme olduğunu söylemek yanlış olmayacaktır. (Arslan, 2009, s.265)

Aristoteles'e göre ölçülülük, bilgelik, cesaret gibi diğer tüm erdemler kişinin kendi ile ilgilidir. Ancak adalet hem diğer erdemleri hem de başkalarıyla olan ilişkiyi kapsadığı için tamdır ve en çok kendine yeten erdemdir. Bu da adalet için aslında toplumsal iyi demenin başka bir ifadesidir. (Arslan, 2009, s.265) Aristoteles için insanlar işlerinde diğer erdemleri kullanabilir ancak başkalarının işinde bunları kullanmazlar ve bu durum erdemsiz oldukları anlamına gelmez: Yalnızca toplumsal konular, ona göre bahsi geçen erdemlerin kapsayıcılıklarının dışındadır. Bu anlamda tekrar ifade etmek gerekirse, adalet tam olduğu için, kendi amacını kendinde en çok taşıyan erdemdir. Bu nedenle Aristoteles, adaletin, sık sık en önemli erdem olarak düşünüldüğünü söyler. Adalet, yöneticilerin başkalarıyla ilişkili olması bakımından ve bu ilişki içinde yararlı olanı, mutluluğu amaçlamaları bakımından politikayla ilişkilidir. Yönetici adil olduğu zaman, diğer erdemleri de içinde taşıyarak yargı dağıtır. Çünkü ona göre adalet erdemin bir parçası değil, bütünüdür. Adaletsizlik de kötülüğün bütünüdür. (Aristoteles, 2015a, s.92-93)

Aristoteles iki tür adaletten (bunlar da bütün olan adaletin parçalarıdır) bahseder. Ona göre, ilk tür adalet, onurun, paranın ya da yurttaşlar arasında bölüştürülebilir şeylerin dağıtılması ile ilgilidir. Diğer tür ise alışverişlerde düzeltici işlevi görür. Aristoteles bu noktada iki tür alışverişten söz eder. İlki isteyerek yapılan alışveriş ki bunun içinde satmak, satın almak, borç 
vermek vb. durumlar yer alırken, ikincisi istemeyerek yani zora dayanan alışverişlerdir. Bunlar da baştan çıkarma, hırsızlık, tuzak kurma gibi durumlarla ilgilidir. (Aristoteles, 2015a, s. 93-95)

Aristoteles, etik öğretilerinde uyguladığı orta yolu adaletin türlerini açıklarken de kullanmaktadır. Buna göre, bölüşülen mallar taraflara eşit şekilde dağıtılmalıdır. Ancak Aristoteles eşitliği mutlak bir eşitlik ya da aynı payı alma olarak anlamaz. Ona göre eşit olan şey, kişilerin aldıkları payların oranlarının birbirine eşit olmasıdır. Başka bir ifadeyle, kişilere dağıtılan paylar, kişilerin durumlarına göre değişir. Farklı pozisyonda olan iki kişi, farklı paylar almaktadır ancak bu paylar, hak ettiklerinden ne az ne de çok olmak kaydıyla ortada eşit veya hakkaniyetli bir bölüşme söz konusu olacaktır. Daha açık bir ifadeyle, bu insanlar mevkii, ekonomik düzey, vb. durumlar bakımından eşitse, dağıtılacak şey eşit olacaktır, değilse eşit olmayacaktır. (Arslan, 2009, s.266) Ancak bu değer farklı toplum türlerinde farklı şekilde anlaşılmaktadır. Demokrasi ile yönetilen toplumlarda özgürlük, oligarşi yanlılarına göre zenginlik ve soyluluk, aristokrasi ile yönetilen toplumlar açısından da erdem değerlidir. Bu türden adalet, Aristoteles'e göre, “dağıtıc1” adalettir. (Aristoteles, 2015a, s.96-97)

Bir diğer adalet ise "düzeltici" adalettir. Bu adalet türünde diğerine göre önemli olan orantı değil, mutlak eşitliktir. Adaleti sağlayacak olan eşitlik, adaletsizliği getirecek olan ise eşitsizliktir. Burada tarafları eşit olarak kabul eden yasa karşısında yapılan eylemin değerlendirilmesi söz konusudur. İyi bir kişinin ya da kötü bir kişinin cinayet işlemesi değil, sadece cinayet işlenme durumu adil olarak değerlendirilmelidir. Bu noktada adalet, eşit olmayan durumları eşitlemeye çalışmaktır. Aristoteles burada eşitliğin sağlandığı tarafı kazanç, eşitliği sağlamak açısından pay alınan tarafı da zarar olarak ifade etmektedir. Bu bağlamda ona göre adalet, kazanç ve zararın ortasıdır. Daha önce ifade edildiği gibi, etik ve politik anlamda orta olmayı benimseyen Aristoteles, buradaki adaletin de bir tür orta olduğunu ifade etmektedir. Burada önemli olan, yargıcın eşitliği sağlamak adına hangi payı kimden alması ve kime pay eklenmesi konusunda dikkatli olması ve sonucunda adaleti sağlamasıdır. Bu adaleti sağlamaktan kastı ise adil yargıcın tarafları kâr ve zarar durumlarının ortaya çıkmadığı hallerine getirmesidir. (Aristoteles, 2015a, s.97-99)

Aristoteles'in son olarak dile getirdiği adalet türü ise "değiş tokuş" adaletidir. Burada Pythagorasçılara karşı çıkan Aristoteles, bu adalet türü içinde eşitlik bakımından bir karşılıklılık olmadığını ifade eder. Daha açık bir ifadeyle Aristoteles, yaptığının karşılığını aynen almayı adalet olarak düşünmemektedir. Onun bu tür adalette ifade etmek istediği şey "eşdeğer" olması durumudur. (Arslan, 2009, s.268)

Değiş tokuş, toplum içinde yaşayan insanların karşılıklı olarak ihtiyaçlarını gidermesinden doğmaktadır. Nitekim toplumların oluşmasının temel nedeni, insanların farklı ihtiyaçlara sahip olması ve bu ihtiyaçlar doğrultusundaki talepleridir. Bu karşılıklı ihtiyaçların giderilmesi durumunda taraflar, birbirlerine verdikleri şeylerin eşdeğer olmalarını gözetmek durumundadır. Bir örnek ile açıklayacak olursak; bir mimarın yaptığı eve karşılık olarak bir ayakkabıcının yaptığı ayakkabı eşdeğer gelmemektedir. Burada bir eve eşdeğer olan ayakkabı miktarı belirlenmeli ve ona göre bir adalet sağlanmalıdır. Aristoteles bu belirlenimin yapılmasında paranın belirleyici olduğunu ifade eder. Bir evin ve ayakkabının para bakımından değeri belirlendikten sonra ancak kaç evin kaç ayakkabıya denk düşeceği 
belirlenebilecektir. Bu belirlenim sonrasında yapılacak olan adaletli değiş tokuş hem tarafların ihtiyaçlarının giderilmesini hem de toplumdaki bir aradalığı sağlayacaktır. (Aristoteles, 2015a, s. 99-102)

Tüm bu söylenenlerin neticesinde Aristoteles, adaletli eylemin haksızlık etmek ve haksızlığa uğramanın ortası olduğunu ifade eder. Adaletsizlik ise dengedeki iki aşırı uç anlamına gelmektedir. Yasalar, bu adaleti sağlamanın aracı ve güvencesidir. Yöneticiler ise ancak adaletin ve eşitliğin koruyucusudurlar. Bunun karşılı̆̆ı ise onur ve ayrıcalıktır. Bununla yetinmeyenler ise tiran olurlar. Bunların dışında Aristoteles için, yalnızca adaletin veya adaletsizliğin ilgili olduğu durumlar değil, bunun yanında adaletli veya adaletsiz olarak nitelendirilen eylemlerin meydana gelme koşulları ve biçimleri de önemlidir. Buna göre, sonucu bir haksızlık meydana getirmiş olsa bile, her haksız eylem adaletsiz değildir. Örneğin, borcu olan birinin başkasının zorluyla borçlu olduğu kişiye bunu ödememesi bu kişinin rastlantısal olarak haksızlık yaptığı anlamına gelmektedir. Aristoteles bunu adaletsizlik olarak nitelendirmemektedir. Diğer yandan, birine başkasının zoruyla borcunu ödemek, Aristoteles için ne haksızlık ne de haklılık barındıran bir durumdur. Çünkü kişi yine rastlantısal bir eylemde bulunmuştur. Bir diğer örnekte ise bir başkasının zoruyla karşısındaki kişi kim olursa olsun zarar veren bir kişi, bunu isteyerek yapmaz. Burada bir başkasının zoru ile istemeyerek yapması söz konusudur. Ancak önceden düşünüp taşınılan durumların isteyerek, düşünüp taşınılmayan durumların ise rastlantısal ya da istemeyerek yapılmasıdır. (Aristoteles, 2015a, s. 103-105)

Aristoteles'e göre, politik birliğin var olması ve adaletin tesis edilmesi için önemli bir diğer kavram dostluktur. Toplumda mutluluğu ve düzeni sağlayacak olan politik yapının bir diğer temel amacı dostluk sağlamaktır. Bu dostluğu sağlayabilmenin temel aracı ise adalet erdeminin varlığıdır. (Aristoteles, 2015b, s.66) Adalet erdemine sahip olan ve bunu yurttaşlarına kazandıran bir yönetici, o toplum içindeki haksızlıkların olmasını engelleyen ve bu sayede ikili ilişkilerin sağlıklı kurulmasını sağlayan bir kişi olacaktır. Bu duruma ilişkin Aristoteles'in bakışı, kurulacak dostlukların haksızlıkları önleme sebebinin dostların birbirlerine haksızlık etmeme durumu olduğu yönündedir. Bununla birlikte Aristoteles, dostluk kavramını ifade ederken, sadece arkadaşlık olarak nitelendirmemektedir. Aile, komşu, akrabalar, hatta yakın ikili ilişkilerde bulunan tüm insanları kastetmektedir. Burada kurulacak "özel hukuk" kişilerin kendisine bağlıdır, ancak diğeri/başkası ile kurulan ilişkinin bir hak barındırması, önemli bir yurttaşlık bilinci gerektirmektedir. (Aristoteles, 2015b, s.67)

Yurttaşlar arasında uzlaşmaya dayalı dostluğun bulunması toplumsal açıdan kurulacak düzenin bir unsurudur. Bu uzlaşma orantıya dayalı bir eşitlik anlayışı sağlamaktadır ve orantılı olan şey adildir. Aristoteles bu dostluk biçimindeki adaletin sağladığı düzeni aristokrasi ile bağdaştırmaktadır. Aynı zamanda Aristoteles açısından dostluk ilişkisinin nasıl kurulacağını belirlemek, adaletin ne olduğunu araştırmak demektir. Nitekim adalet ortaklar arasında görülür ve dostluk bir ortaklıktır. 


\section{Sonuç}

Görüldüğü üzere, Aristoteles için politika ya da adil yönetim, ekonomik eşitlik, faydanın maksimize edilmesi veya bireysel çıkarların garantörlüğü gibi modern rollerinin dışında farklı bir anlama sahiptir. Aristoteles'in kendi çağının ötesinde sayılabilecek, özellikle politika alanına dair fikirleri, farklı disiplinlerde yürütülen çalışmaların konusu olması bakımından güncelliğini korumaktadır. Bunun durumun nedenlerinden biri, politikanın doğası, işlevi ve asli amacının hâlâ tartışılıyor olmasıdır demek yanlış olmayacaktır. Adalet özelinde konuşmak gerekirse, şüphesiz adalet, insan ruhundaki ve toplumdaki en temel şeydir. Bugün bile kitlelerin en şiddetli biçimde istediği şeydir. Çünkü adaletten daha evrensel, daha güçlü ve daha mükemmel olan bir şey düşünülemez. (Solomon, 2004, s.21)

Günümüzde politikanın, iyi bir yaşamın temel koşulu olarak görülmesi bir yana, o, "şeytani" bir şey olarak kabul edilmektedir. Politika sözcüğü genelde "taviz", yapmacıklık”, "çıar" ve "yozlaşma" gibi kavramlarla ilişkilendirilir. Hatta politikanın ideal tanımları bile onu, bir amaca götüren araç veya diğer meslekler gibi meslek olarak tasarlar. (Sandel, 2017, s.259) Ancak Aristoteles'in dünyasında bu türden politik yozlaşmalar söz konusu olsa bile bunlar insani zafiyetten ve bilgisizlikten kaynaklanmaktadır. Politika, Aristoteles'e göre insanın insanca yaşaması, mutlu ve erdemli bir hayat sürebilmesi, daha da önemlisi, insanın insan olabilmesi için vazgeçilmez bir unsurdur. Çünkü erdemli ve iyi bir hayat sürmek, deyim yerindeyse, evde, felsefe dersinde veya bir etik kitabı okuyarak öğrenilecek bir şey değildir. Ahlaki erdemler, yapılarak öğrenilen ve alışkanlıklar sonucu ortaya çıkan davranışlardır. Tıpkı iyi bir ressam olmak için resim bilgisinin değil, iyi resimler yapmanın gerekli olması gibi, erdemli veya daha özel anlamda, adil olmak da için de eylem zorunlu koşuldur.

Bununla birlikte, Aristoteles'in politika ve adalet öğretisine modern dönemlerde getirilen eleştiriler, onun, adaleti genel anlamda bir uyum sorununa indirgemiş olduğu iddiası etrafında şekillenmektedir. Aristoteles'te uyum, “hakları dağıtmak sosyal kurumların telosunun aramak ve bireyleri kendilerini gerçekleştirmelerine imkân verecek uygun rollere koymaktır. İnsanlara hak ettiklerini verme; onlara hak ettikleri görevleri ve onuru, doğalarına uyumlu sosyal rolleri vermek" (Sandel, 2017, s.265) anlamina gelmektedir. Ancak Kant ve Rawls gibi filozofların temsilcileri oldukları modern liberal adalet teorilerinde, teleolojik yaklaşımdan kaynaklı bir özgürlük kaygısı vardır. Adalet söz konusu olduğunda, asıl önemli olan, bir amaca göre şekillenen uyum değil, seçimdir. Dolayısıyla onlara göre "hakları dağıtma insanları doğalarına uygun rollere uydurmak değildir; insanların rollerini kendi kendilerine seçmelerine izin vermektir." (Sandel, 2017, s.266) Bu bağlamda telos ve uyum kavramları tehlikelidir, çünkü ortaya kişinin doğasına uygun rolü kimin belirleyeceği problemi çıkmaktadır. Birey, kendi özgür rolünü seçemediği durumda belirlenmiş bir rolü kabul edilmeye zorlanması söz konusudur. Bu bağlamda, gücü elinde bulunduran otorite, kişiye daha aşağı bir rolü uygun görürse, Aristoteles'in anlayışındaki gibi, hak olarak dağıtılan şeyin ve dağıtılan kişinin doğası temelinde biçimlenen adalet öğretisi, kolaylıkla köleliği ortaya çıarabilir. (Sandel, 2017, s.267)

Ancak getirilen bu türden eleştirilerin, haksız bir tutum olduğunu dile getirmekte yanlış olmayacaktır. Çünkü Aristoteles'in felsefesi söz konusu olduğunda, dağıtılan hakların dağıtılan şey ve insanın toplumsal alandaki doğasına göre belirlenmesi, kişinin doğasının otorite tarafından belirleneceği anlamına gelmemektedir. Yurttaşlara veya poliste yaşayanlara 
dağıtılan roller ve paylar, bir ön belirlenim dışında, kişinin özgür seçimleriyle biçimlenen karakteri ve doğasına göre şekillenmektedir. Bir diğer ifadeyle, kişi politik birliğin ortak iyisi ve mutluluğu için ne kadar sorumluluk alırsa o kadar onur ve haklara sahip olur. Bununla birlikte politikaya, yurttaşların mutluluğu gibi bir telosun belirlenmesinin problem teşkil etmesi bir yana, tam da çağımızda yaşanan politik sorunların temelinde unutulan bu telosun yattığını ve politika bu biçimde görülürse, bu sorunlar için bir panzehir işlevine sahip olacağını söylemek yanlış olmayacaktır.

\section{Kaynakça}

Aristoteles. (2015b). Eudemos'a Etik, çev. Saffet Babür, Ankara: BilgeSu Yayıncılık.

Aristoteles. (2015a). Nikomakhos'a Etik, çev. Saffet Babür, Ankara: BilgeSu Yayıncılık.

Aristoteles. (2018). Politika, çev. Özgüç Orhan, İstanbul: Pinhan Yayıncılık.

Arslan, A. (2006). Il kçă̆ Felsefe Tarihi 2, Sofistlerden Platon'a, İstanbul: İstanbul Bilgi Üniversitesi Yayınları.

Arslan, A. (2009). İlkçă̆g Felsefe Tarihi 3, Aristoteles, İstanbul: İstanbul Bilgi Üniversitesi Yayınları.

Copleston, F. (2009). Felsefe Tarihi: Ön-Sokratikler ve Sokrates, çev. Aziz Yardımlı, İstanbul: İdea Yayınevi.

Herakleitos. (2009). Fragmanlar, çev. Cengiz Çakmak, İstanbul: Kabalcı Yayınevi.

Jaeger, W. (2012). Ilk Yunan Filozoflarında Tanrı Düşüncesi, çev. Güneş Ayas, İstanbul: İthaki Yayınları.

Platon. (2012). Yasalar, çev. Candan Şentuna, Saffet Babür, İstanbul: Kabalcı Yayıncılık.

Sandel, M. J. (2017). Adalet: Yapılması Gereken Doğru Şey Nedir?, Ankara: Felix Kitap.

Solomon, R. C. (2004). Adalet Tutkusu, çev. Ertuğrul Altınay, İstanbul: Ayrıntı Yayınları. 